\title{
Effect of Ethanolic leaves Extracts of Annona Muricata. Linn on Hyperlipidemic Rats
}

\author{
Nesrein, S.Salim; Enas M.Mekawi ;Ibrahem, M.Abd El-Aleem and Nadia, Y.A.Attia \\ Department of Biochemistry Faculty of Agriculture, Benha University, Egypt. \\ Corresponding Author: nesreen.salem@fagr.bu.edu.eg, nesrein_2050@yhoo.com
}

\begin{abstract}
Annona muricata (soursop) is an evergreen tropical which has become an important crop because of its tasty flavor, high pulp content, and nutritional value and antioxidant properties. This study aimed to determine the phytochemicals as well as antioxidants present in the plant. The ethanolic leaf extract contains a high phenol content and flavonoide $508.27 \mathrm{mg} / \mathrm{GAE}$ (Gallic acid equivalence) extract and $35.99 \mathrm{mg} / \mathrm{QE}$ (quercetin equivalents) extract respectively. Ethanolic extract of annona muricata leaves was tested for antioxidant capacity with DPPH (1,1-diphenyl-2-picrylhydrazyl) and ABTS (2,2-azino-bis (3-ethlbenzthiazoline-3-sulfonic acid)) method. The result showed that antioxidant capacity of annona leaves were $85.9 \%$ and 79.29, respectively. Oral ethanolic extracts of adminstration of Annona at different levels (200 and $300 \mathrm{mg} / \mathrm{kg}$ ) to albino rats showed significant decrease in liver , and kidney functionse, levels of total lipids, triglycerids, total cholesterol and LDL-cholesterol comparing with positive control.
\end{abstract}

Keywords: Annona muricata Linn.; Antioxidant capacity; DPPH; extraction, hyperliedimic.

\section{Introduction}

Increment of blood cholesterol is one of the most threatening causes of human life nowadays because it is a risk factor for many diseases including heart disease, atherosclerosis and high blood pressure. Hence the idea of this study is to find out the effectiveness of natural antioxidants in some medicinal plants in improving stress in mice infected with hyperlipidemia experimentally by raising the level of cholesterol and colic acid food.

In the recent years, there has been gradual revival of interest in the use of medicinal plants in developing countries because hearbal medicines have been reported safe and without any adverse side effect especially when compared with synthetic drugs.

Annona muricata, commonly known in English speaking countries as 'soursop' in Yoruba. Traditionally, the leaves are used for headaches, insomnia, cystitis, liver problems, diabetes, hypertension and as an anti-inflammatory, antispasmodic and anti-dysenteric (Di Stasi and Hiruma-Lima, 2002 and Sousa et al., 2004). In West Indies, various parts of the plant, including the leaves, bark and roots have been used to treat disease conditions such as diabetes (Adeyemi et al., 2008, 2010) and arthritis. Other reported medicinal uses of Annona muricata include its anticancer (Oberlies $\boldsymbol{e t}$ al., 1997 and Liaw et al., 2002), antibacterial and antifungal actions, as well as, its antinociceptive and anti-inflammatory effects (De Sousa et al., 2010). The plant has been reported to possess acetogenins as major phytoconstitutents (Padma et al., 1996) which are responsible for a number of activities such as antitumor, immunomodulator, anti-spasmodic, antimalarial. pesticidal, anti-parasitic, anti-bacterial, antifungal activity (Padma, 1997).

Phytochemical screening of the plants showed the presence of alkaloids, carbohydrate, coumarins, flanonoids, phenolic compounds, phytosterols, [rotein, quonones saponins, sterioids and terpenoids (Vijayameena etal., 2013).

\section{Materials and Methods}

The Annona muricata leave were obtained from agricultural research station farm, Faculty of Agriculture at Moshtohor ,Benha university. Sample were collected in 2017.

Minerals salts of potassium(K) and sodium (Na) were measured by flame-photometer and phosphorus (p) was determined colorimetrically. However, other metals i.e. $\mathrm{Fe}, \mathrm{Ca}, \mathrm{Zn}, \mathrm{Mn}, \mathrm{Mg}$ and $\mathrm{Cu}$ were determined by atomic absorption according to the method described in A.O.A.C. (2005).

\section{Preparation of Annona leaves extract:}

The dried leaves was powdered mechanically and soaked with $80 \%$ ethanol $(1: 10)$ in brown bottles at room temperature $\left(25-30^{\circ} \mathrm{C}\right)$ in dark place for 7 day and mix gently every day. The mixture was filtrated by suction pump in buchar funnel throw filter paper and concentrated to dryness using rotary evaporator and freeze dry.These crystals were weighted, dissolved in disttiled water and administrated orally to the experimental animal for the treatment of hyperlipidemic according to (Sulaiman et al., 2012,).

\section{Determination of total phenolic compounds}

The concentration of total phenols in ethanolic extracts were measured by a UV spectrophotometer (SM1600UV-visSpectrphotometers, Azzota, USA), based on a colorimetric oxidation/reduction reaction as described by Skerget $\boldsymbol{e t}$ al. (2005). The used oxidizing reagent was Folin-Ciocalteu reagent (AOAS, 1990). To $0.5 \mathrm{ml}$ of diluted extract $(10 \mathrm{mg}$ in $10 \mathrm{ml}$ solvent ) $2.5 \mathrm{ml}$ of was Folin-Ciocalteu reagent and $2 \mathrm{ml}$ of $\mathrm{Na}_{2} \mathrm{CO}_{3}(75 \mathrm{~g} / \mathrm{L})$ were added. 
The samples were incubated for $5 \mathrm{~min}$ at $50^{\circ} \mathrm{C}$ and then cooled. For control sample $0.5 \mathrm{ml}$ of distilled water was used. The absorabance was measured at $760 \mathrm{~nm}$.

\section{Determination of total flavonoids}

Total flavonoids content was determined by the method of Ordon et al. (2006) with some modification. A $1.5 \mathrm{ml}$ aliquot of $20 \mathrm{~g} / \mathrm{L} \mathrm{AlCl}_{3}$ ethanolic solution were added to $0.5 \mathrm{~mL}$ of extract solution $(10 \mathrm{mg}$ in $10 \mathrm{ml}$ solvent). After one hour of addition the absorbance at $420 \mathrm{~nm}$ was measured at room temperature. A yellow color indicated the presence of flavonoids. Extract samples were evaluate at a final concentration of $\mathrm{mg} / \mathrm{mL}$.

DPPH (2, 2-diphenylpicryhydrazyl) radicalscavening activity:

The electron donation ability of the obtained extracts was measured by bleaching of the purple colored solution of DPPH according to the method of Hanato et al. (1988). One hundred $\mu \mathrm{L}$ of each extract $(10 \mathrm{mg}$ extract $/ 10 \mathrm{ml}$ solvent) was added to 3 $\mathrm{ml}$ of $0.1 \mathrm{mM}$ DPPH dissolved in ethanol. After incubation period $30 \mathrm{~min}$ at room temperature, the absorbance was determined against a control at 517 nm (Gulcin et al., 2004). Percentage of antioxidant activity of free radical DPPH was calculated as follows:

Antioxidant activity (inhibition) $\%=\left[\left(\right.\right.$ A control - $_{\text {- }}$ Asample ) / Acontrol ] $\times \mathbf{1 0 0}$

where Acontrol is the absorbance of the control reaction and $\mathrm{A}_{\text {sample }}$ is the absorbance in the plant extract. TBHQ (Tert-butyl hydroquinone) was used as a positive control. Samples were analyzed in triplicate.

ABTS (2,2-azino-bis (3-ethlbenzthiazoline-3sulfonic acid) radical-scavenging activity :

For the ABTS assay the method of Re $\boldsymbol{e t}$ al. (1999) have been used. The stock solution was 7 $\mathrm{mmol} / \mathrm{L}$ ABTS solution and $2.4 \mathrm{mmol} / \mathrm{L}$ potassium per sulfate solution. The working solution was prepared by mixing the two stocks in equal quantities and allowing them to react for $12-16 \mathrm{~h}$ at room temperature in the dark. One $\mathrm{ml}$ of the resulting ABTS $^{+}$solution was diluted with $60 \mathrm{ml}$ methanol. ABTS $^{+}$solution was freshly prepared for each assay. Ten $\mu 1$ of each extract $(10 \mathrm{mg}$ extract $/ 10 \mathrm{ml}$ solvent) and (TBHQ solution) were allowed to react with $5 \mathrm{ml}$ of ABTS $^{++}$solution for $7 \mathrm{~min}$, then the absorbance at $734 \mathrm{~nm}$ was recorded. A control with no added extract was also analyzed. Scavenging activity was calculated as follows:

ABTS radical scavenging activity $(\%)=[$ (Abs control - Abs sample ) /Abs control $\times 100$

Where Abs control is the absorbance of ABTS radical + methanol and Abs sample is the absorbance of ABTS radical + extract/synthetic antioxidant.

\section{HPLC analysis:}

The dried hydrolyzed ethanolic extracts were dissolved in HPLC grade methanol $1.0 \mathrm{mg} / \mathrm{ml}$ ), filtered through sterile $0.22 \mathrm{~m} \mathrm{~m}$ Millipore filter and subjected to qualitative and quantitative analysis by using HPLC instrument. The instrument equipped with a dual-pump LC-L OAT binary system HPLC, a UV detector SPD-10A, and a phenomenex Luna RP,C 18 column (4.6 s $250 \mathrm{~mm})$. Data were integrated by Shimsadzu Class VP series soft ware.Separation was achieved with an acetonitrile/water containing $1 \%$ acetic acid linear gradient program, started with $18 \%$ acetonitrile. Changing to $32 \%$ in $15 \mathrm{~min}$ and finally to $50 \%$ in 40 min. Results were obtained by comparison of peaks areas $(\lambda \max =254 \mathrm{~nm})$ of the samples $(\mathrm{mg} / \mathrm{g}$ dry extract) with that of standard (Prakash , 2007)

\section{Statistical analysis of the data:}

Statistical analysis was carried out using ANOVA with one factor under significance level of 0.05 for the whole results using SPSS var.19 and data were treated as complete randomization design according to Steel et al. (1997). Multiple comparisons were carried out applying LSD.

\section{Biological experimental:}

This experiment was performed to investigate the effect of Annona leaves ethanolic extract on albino rats. This study was conducted with biochemical parameters of blood and observations of abnormal clinical symptoms and mortality rate.

Rats were allowed to be acclimatized to laboratory condition for two weeks prior to the experiment. The rats were housed in stainless steel cage under good hygienic conditions in dry-bulb temperature $25 \pm 2^{\circ} \mathrm{C}$ and fed on a basel diet then fed on modifided high fat diet (MHFD) showen in table (1).

Table 1. The composition of modified high fat diet

\begin{tabular}{lc}
\hline Ingredient & Amount (g/kg diet) \\
\hline Corn Starch & 578.55 \\
Casein & 150 \\
Sheep fat & 50 \\
Salt mixture & 40 \\
Vitamins mixture & 10 \\
Cellulose & 100 \\
Cholesterol & 10 \\
Bile salts & 2.5 \\
\hline
\end{tabular}

This composition modified after Fukushima etal .(1997)

\section{Experimental design:}

A total of 30 adult male albino rats (Wister Strain) weighted 118 to $152 \mathrm{~g}$ were obtained from the farm of atomic Energy Authority, Inshas. Egypt. They were kept in wire -bottom stainless steel cage in a room temperature maintained $25 \pm 2{ }^{\circ} \mathrm{C}$. Rats were kept under normal healthy condition for 14 days and fed on a basal diet. 
The diet contained of $65 \%$ starch, $15 \%$ casein, $10 \%$ corn oil, $5 \%$ cellulose, $4 \%$ minerals and $1 \%$ vitamins.

Dosage and administration of decoction: The decoction was administered at a doses of $10 \mathrm{mg} / \mathrm{kg}$ Atorvastetine, $200 \mathrm{mg} / \mathrm{Kg}$ and $300 \mathrm{mg} / \mathrm{kg}$ body weight annona leaves ethanol extract (Ahalya et al. ( 2014), using a Sondi needle by gastric gavage. After that animals were divided into two main groups.

First main group (6 rats): negative control (healthy control) without any treatment. The Second main group (24 rats): was induced by modified high fat diet (MHFD) and divided into:First subgroup (6 rats) was kept as hyperlipidemic (positive control) and fed on MHFD for eight weeks.Second subgroup (6 rats) was fed a MHFD and received orally Atorvastatin as stander cholesterol-lowering drug $10 \mathrm{mg} / \mathrm{kg}$ body weight/day for eight weeks.(Sakr et al 2009).Third subgroup (6 rats) was fed a MHFD diet and received orally annona ethanol extract $200 \mathrm{mg} / \mathrm{kg}$ body weight/day for eight weeks.Fourth subgroup (6 rats) was fed a MHFD diet and received orally annona ethanol extract $300 \mathrm{mg} / \mathrm{kg}$ body weight/day for eight weeks.

\section{Blood samples:}

After 8 weeks from the administration of the different treatments, blood samples were obtained from the retro-orbital plexus of overnight fasted rats. Blood was collected into a plain centrifuge tube at $3000 \mathrm{rpm}$ for $20 \mathrm{~min}$ for serum preparation and assay of the biochemical parameters of blood including liver function tests, kidney function tests and serum cholesterol

\section{Result and Discussion}

\section{Minerals content of Anonna leaves}

Minerals content are considered as important for human growth, animals and plants. Calcium and phosphorus are essential elements for metabolic processes in all living microorganisms. Also magnesium is an important element for activation enzyme reaction. On the other hand, iron and zinc are essential elements in physiological metalo-enzymes systems (Laster and Birkeh ,1999).

Minerals contant of Anonna leaves was determined and the obtained results were presented in Table (2).

Table 2. Minerals content of anonna leaves $(\mathrm{mg} / 100 \mathrm{~g})$

\begin{tabular}{cc}
\hline \multirow{2}{*}{ Minerals } & Anonna muricata $(\mathbf{m g} / \mathbf{1 0 0 g})$ \\
\cline { 2 - 2 } & Leaves \\
\hline $\mathbf{C a}$ & 598.2 \\
$\mathrm{Mg}$ & 211.9 \\
$\mathrm{~K}$ & 617.1 \\
$\mathbf{N a}$ & 125.51 \\
$\mathbf{P}$ & 80.5 \\
$\mathbf{F e}$ & 7.73 \\
$\mathbf{C u}$ & 1.71 \\
$\mathbf{M n}$ & 19.51 \\
\hline
\end{tabular}

From Table (2) it could be noticed that Anonna contained considerable amounts of $\mathrm{K}, \mathrm{Ca}, \mathrm{Mg}$, and $\mathrm{Na}$. Results are in agreement with pervious finding reported by Kimbonguila etal., (2010) .

Total Phenolic compounds,total flavonoids and anti radical activity of Annona muricata leaves :

Data presented in Table (3) show that ethanolic extracts yield of annona muricata was $22.01 \%$. However total phenolic contents of annona muricata leaves extract was $508.27 \mathrm{mg} / \mathrm{GAE}$ extract. While total flavonoids was $35.99 \mathrm{mg} / \mathrm{QE}$ extract. The obtained results are inagreement with those reported by Yahaya etal., (2014) and Carle et al.,(2010).

\section{Antioxidant activity of the ethanolic extracts:}

Ethanolic extracts from annona muricata leaves showed strong scavenging activity against DPPH and ABTS radicals Table (3).

Table 3. Ethanolic extract yield, total phenolic, total flavonoid and antiradical activities of annona muricata leaves extract :

\begin{tabular}{|c|c|c|c|c|c|}
\hline \multirow[b]{2}{*}{ Material } & \multirow[b]{2}{*}{ Total extract $\%$} & \multirow{2}{*}{$\begin{array}{l}\text { Total phenolic mg } \\
\text { GAE/ g extract }\end{array}$} & \multirow{2}{*}{$\begin{array}{l}\text { Total } \\
\text { flavonoids mg } \\
\text { QE/g extract }\end{array}$} & \multicolumn{2}{|c|}{ Antiradical activity } \\
\hline & & & & $\begin{array}{c}\text { DPP } \\
\text { H }\end{array}$ & ABTS \\
\hline annona muricata & 22.01 & 508.27 & 35.99 & 85.9 & 79.29 \\
\hline leaves extract & \pm 1.45 & \pm 0.14 & \pm 0.95 & \pm 1.51 & \pm 1.17 \\
\hline
\end{tabular}

From the above mentioned data it is clear that samples with low content phenolic compounds have lower antioxidant activity. The antioxidant activity of phenolic compounds are to be largly determined by the number of hydroxyl groups on the aromatic ring. The higher number of hydroxyl groups, the greater expected antioxidant activity. These results are in agreement with (Baskar etal., 2007).

Phenolic compounds are commonly found in both edible and non-edible plants, and they have been reported to have multiple biological effects including antioxidant activity. Crud extract of herbs , vegetables and others plant materials are rich in phenolic compounds which retard oxidative degradation of lipids, due to improvement the quality and nutritional value of food. The importance of the antioxidant constituents of plant materials is the maintenance of health and protection from coronary heart disease and cancer (Loliger 1991). 
4.3. Identification of some antioxidant components of Annona Muricata leaves ethanolic extract by HPLC:

Data presented in Table (4) show the chemical constituents of the ethanolic extract of annona leaves. Annona muricata ethanolic extract revealed the presence 21 phenolic compound .The highest quantities were Catechein followed by ,Pyrogallol
,Benzoic, salycillic , Chlorogenic, Caffeine , Ellagic, Protocatchuic and P-OH-benzoic.

Also results in table (5)showed the presence 15 flavonoids compound in annona leaves ethanolic extract.The highest values was Naringin,Hespirdin,Rutin, Quercetrin ， and Kamp.3,(2-p-comaroyl)glucose. The obtained results are inagreement with those reported by George et al (2012), and Chunhua et al (2015),

Table 4. Phenolic compounds of annona muricara leaves ethanolic extracts analyzed by HPLC

\begin{tabular}{lcc}
\hline & Phenolic compounds & $\mathbf{m g} / \mathbf{1 0 0 g}$ \\
\hline 1 & Gallic & 76.45 \\
2 & Pyrogallol & 414.53 \\
3 & 4 -aminobenzoic & 18.76 \\
4 & Protocatchuic & 153.67 \\
5 & Catechein & 778.59 \\
6 & Chlorogenic & 271.57 \\
7 & Catechol & 72.34 \\
8 & Caffeine & 209.53 \\
9 & p-OH-benzoic & 136.27 \\
10 & Caffeic & 21.09 \\
11 & Vanillic & 96.03 \\
12 & P-coumaric & 32.41 \\
13 & Ferulic & 24.55 \\
14 & Ios-ferulic & 26.02 \\
15 & Ellagic & 159.23 \\
16 & Alpha-coumaric & 12.40 \\
17 & Benzoic & 373.85 \\
18 & Salycillic & 275.47 \\
19 & Coumarin & 17.15 \\
20 & Cinnamic & 24.25 \\
21 & & 11.24 \\
\hline
\end{tabular}

Table 5. Flavonoids of annona muricara leaves ethanolic extracts analyzed by HPLC .

\begin{tabular}{ccc}
\hline & Flavonoids & $\mathbf{M g} / \mathbf{1 0 0 g}$ \\
\hline 1 & A Pig.6-arbinose 8- galactose & 62.77 \\
2 & A Pig.6- rhamnose 8- glicose & 68.35 \\
3 & luteolin 7-glucose & 179.61 \\
4 & Naringin & 3200.549 \\
5 & Rutin & 129.743 \\
6 & Hespirdin & 1300.56 \\
7 & Apigenin.7 o-neohes & 25.90 \\
8 & Quercetrin & 510.07 \\
9 & Quercetin & 19.84 \\
10 & kamp.3(2pcomaroyl)glucose & 183.57 \\
11 & Naringenin & 6.99 \\
12 & Kampferol & 31.86 \\
13 & Acacetin neo.rutinoside & 77.83 \\
14 & Hespirtin & 59.10 \\
15 & Apegnin & 27.98 \\
\hline
\end{tabular}

\subsection{Biological evaluation}

Hypercholesterolemia has been associated with enhancment oxidative stress related to increment of lipid peroxidation. Increased generation of oxidized LDL is a major factor in the vascular damage associated with high cholesterol levels. Hence the inhibition stress under hypercholerterolemic condations is considered to be an important therapeutic approach and efforts have been made to identify the antioxidative functions of various 
medicinal plants (Adaramoye etal .,2008).After 8 weeks of experiment period, lipid profile, liver function and kidney function were determined.

4.4.1. Effect of ethanolic extract of Annona muricata on body weight gain of hyperlipidemia rats after 8 weeks

Initial body weights and final body weights of rats fed with annona muricata extracts (200 and $300 \mathrm{mg} / \mathrm{kg} \quad$ B.W.)were recorded during the experimental period (8 weeks).

Data reported in table (6) indicated that the initial weights of rats were found to be $153.61 \pm 0.4$ and $150.41 \pm 1.02 \mathrm{~g}$ for normal and hyperlipidemic groups respectively, while the values were
$151.99 \pm 1.13$ and $145.6 \pm 0.96 \mathrm{~g}$ for groups treated 200 and $300 \mathrm{mg} / \mathrm{kg}$ annona muricata extracts, respectively.

The obtained results show that rats fed high cholesterol diet had the highest values of final body weight and body weight gain $(315.77 \pm 1.57$ and $165.36 \pm 0.63 \mathrm{~g}$ ) comparing with basal diet $(289.92 \pm 0.59$ and $136.32 \pm 0.34 \mathrm{~g})$ and atorvastiteine drug $(295.24 \pm 0.57,145.8 \pm 0.99)$. These results are in harmony with those of Jayasooriya etal.,(2000) and Barakat and Mahmond (2011).

In this study the body weights in hyperlipidemic rats decreased significantly due to treatment of annona muricata $(200 \mathrm{mg} / \mathrm{kg})$

Table 6. Effect of ethanolic extract of Annona body weight gain on hyperlipidemia rats after 8 weeks:

\begin{tabular}{|c|c|c|c|c|}
\hline \multirow{2}{*}{ Group } & \multirow{2}{*}{$\begin{array}{l}\text { Initial body } \\
\text { weight (g) }\end{array}$} & \multirow{2}{*}{$\begin{array}{l}\text { Final body } \\
\text { weight }(g)\end{array}$} & \multicolumn{2}{|c|}{ Change body weight gain } \\
\hline & & & (g) & $(\%)$ \\
\hline Control (-ve) & $153.61 \pm 0.4$ & $289.92 \pm 0.59$ & $136.32 \pm 0.34$ & $88.75 \pm 0.28^{\mathrm{e}}$ \\
\hline Control (+ve) & $150.41 \pm 1.02$ & $315.77 \pm 1.57$ & $165.36 \pm 0.63$ & $109.95 \pm 0.48^{\mathrm{ab}}$ \\
\hline $\begin{array}{l}\text { HFD + atorvastiteine drug } \\
10 \mathrm{mg} / \mathrm{kg}\end{array}$ & $149.44 \pm 0.53$ & $295.24 \pm 0.57$ & $145.8 \pm 0.99$ & $97.57 \pm 0.99^{\mathrm{d}}$ \\
\hline $\begin{array}{l}\text { HFD + Annona } \\
(200 \mathrm{mg} / \mathrm{kg})\end{array}$ & $151.99 \pm 1.13$ & $303.9 \pm 0.86$ & $151.90 \pm 0.80$ & $99.96 \pm 1.16^{\mathrm{cd}}$ \\
\hline $\begin{array}{l}\text { HFD + Annona } \\
(300 \mathrm{mg} / \mathrm{kg})\end{array}$ & $145.6 \pm 0.96$ & $308.77 \pm 0.82$ & $163.17 \pm 1.07$ & $112.08 \pm 1.36^{\mathrm{a}}$ \\
\hline
\end{tabular}

\subsubsection{Effect of ethanolic extracts of Annona on liver function of hyperlipidemia rats after 8 weeks:}

Asparatate transaminase (AST), alanine transaminase (ALT) and alkaline phosphatase (ALP) activities in human and experimental animals blood are most frequently measured for diagnosis of liver diseases particularly inefective hepatitis, alcoholic cirrhosis, biliary obstruction, toxic hepatitis and liver cancer (Weber et al. 2002).

Therefore, the effect of oral administration of ethanolic extracts of annona muricata leaves on liver functions (AST, ALT and ALP) activities in hyperlipidemic rats investigated and the obtained results are presented in Table (7).

Table 7. Effect of ethanolic extract of Annona on liver function of hyperlipidemia rats after 8 weeks:

\begin{tabular}{|c|c|c|c|c|c|c|}
\hline \multirow[b]{2}{*}{ Treatments } & \multirow{2}{*}{$\begin{array}{l}\text { AST } \\
(\mathbf{U} / \mathbf{L})\end{array}$} & \multirow{2}{*}{$\begin{array}{c}\text { ALT } \\
(\mathbf{U} / \mathbf{L})\end{array}$} & \multirow{2}{*}{$\begin{array}{l}\text { ALP } \\
(\mathbf{U} / \mathbf{L})\end{array}$} & \multicolumn{3}{|c|}{ Bilirubin } \\
\hline & & & & $\begin{array}{c}\text { Total } \\
(\mathrm{mg} / \mathrm{dl})\end{array}$ & $\begin{array}{l}\text { Direct } \\
(\mathrm{mg} / \mathrm{dl})\end{array}$ & $\begin{array}{c}\text { Indirect } \\
(\mathrm{mg} / \mathrm{dl})\end{array}$ \\
\hline \multirow{2}{*}{ Control negative } & 87.33 & 47.00 & 88.90 & 0.55 & 0.27 & 0.29 \\
\hline & $\pm 2.40^{\mathrm{d}}$ & $\pm 2.08^{\mathrm{d}}$ & $\pm 3.40^{\mathrm{de}}$ & $\pm 0.01^{\mathrm{e}}$ & $\pm 0.01^{\mathrm{d}}$ & $\pm 0.00^{\mathrm{b}}$ \\
\hline \multirow{2}{*}{ Control positive } & 165.33 & 86.00 & 202.71 & 0.91 & 0.57 & 0.33 \\
\hline & $\pm 12.91^{\mathrm{a}}$ & $\pm 1.73^{\mathrm{a}}$ & $\pm 8.28^{\mathrm{a}}$ & $\pm 0.01^{\mathrm{a}}$ & $\pm 0.02^{\mathrm{a}}$ & $\pm 0.01^{\mathrm{a}}$ \\
\hline \multirow{2}{*}{$\begin{array}{l}\text { HFD + Atrovastitine drug } \\
100 \mathrm{mg} / \mathrm{kg}\end{array}$} & 111.33 & 57.00 & 96.52 & 0.64 & 0.37 & 0.27 \\
\hline & $\pm 6.33^{\mathrm{cd}}$ & $\pm 1.73^{\mathrm{c}}$ & $\pm 2.25^{\mathrm{d}}$ & $\pm 0.01^{\mathrm{d}}$ & $\pm 0.01^{\mathrm{c}}$ & $\pm 0.00^{\mathrm{b}}$ \\
\hline \multirow{2}{*}{ HFD + Annona 200mg/kg } & 110.33 & 55.00 & 92.03 & 0.66 & 0.37 & 0.29 \\
\hline & $\pm 5.93^{\mathrm{cd}}$ & $\pm 5.29^{\mathrm{cd}}$ & $\pm 2.17^{\mathrm{de}}$ & $\pm 0.01^{\mathrm{d}}$ & $\pm 0.02^{\mathrm{c}}$ & $\pm 0.00^{\mathrm{b}}$ \\
\hline \multirow{2}{*}{ HFD + Annona 300mg/kg } & 134.00 & 70.67 & 158.69 & 0.80 & 0.46 & 0.34 \\
\hline & $\pm 4.04^{\mathrm{bc}}$ & $\pm 2.19^{\mathrm{b}}$ & $\pm 3.15^{\mathrm{b}}$ & $\pm 0.02^{\mathrm{b}}$ & $\pm 0.01^{\mathrm{b}}$ & $\pm 0.01^{\mathrm{a}}$ \\
\hline
\end{tabular}

$\mathrm{a}, \mathrm{b} \& \mathrm{c}$ :There is no significant difference $(\mathrm{P}>0.05)$ between any two means, within the same column have the same superscript letter.

From the above results it could be observed that the enzymes activities in serum of the control negative group were found to be $87.33 \pm 2.40$, $47.00 \pm 2.08$, and $88.90 \pm 3.40 \mathrm{U} / \mathrm{L}$ after 8 weeks for AST,ALT and ALP ,respectively. While in the case of hyperlipidemia rats the mean values of these parameters

were incrased to, $165.33 \pm 12.91,86.00 \pm 1.73$ and $202.71 \pm 8.28 \mathrm{u} / \mathrm{l}$.

From the above mentioned results could be concluded that AST,ALT and ALP activities were significantly increased in serum of hyperlipidemia rats comparing with these activates of control group 
and Atrovastitine drug . Oral administration of ethanolic Annona muricata extracts at (200 and 300 $\mathrm{mg} / \mathrm{kg}$ ) doses indicated significant decrease in (AST,ALT and ALP) enzymes comparing with hyperlipidemic rats .These means values were found to be $(110.33 \pm 5.23$ and $134.00 \pm 4.04 \mathrm{u} / \mathrm{l})$ for AST, $(55.00 \pm 5.29$ and $70.67 \pm 2.19 \mathrm{u} / 1)$ for ALT and $(92.03 \pm 2.17$ and $158.69 \pm 3.15 \mathrm{u} / \mathrm{l})$ for ALP at $(200$ and $300 \mathrm{mg} / \mathrm{kg}$ ) levels respectively.

These reduction may be due to the major bioactive antioxidant compounds in annona muricata such as polyphenol and flavonoids.

\section{Total and Direct Bilirubinin}

It is well known that accumulation of total and direct bilirubin in blood is an important marker of liver damage and metabolic disturbance in liver if the liver is unable to conjugate bilirubin and form bilirubin glucuronoids which is recreated into bile or if there is excessive obstruction red cell, bilirubin may accumulate in blood.

Data presented in Table (7) indicate that hyperlipidemic rats showed significant increase in total bilirubin and direct bilirubin $(0.91 \pm 0.01$ and
$0.57 \pm 0.02 \mathrm{mg} / \mathrm{dl})$ comparing with normal rats $(0.55 \pm 0.01$ and $0.27 \pm 0.01 \mathrm{mg} / \mathrm{dl})$ and Atrovastitine $\operatorname{drug}(0.64 \pm 0.01,0.37 \pm 0.01)$ respectively.

The obtained results in table (7) show that hyperlipidemic rats when administrated with oral ethanolic extracts of annona (200 and $300 \mathrm{mg} / \mathrm{kg}$ ) showed significant decrease in total and direct bilirubin $(0.66 \pm 0.01$ and $0.37 \pm 0.02 \mathrm{mg} / \mathrm{dl})$ and $(0.80 \pm 0.02$ and $0.46 \pm 0.01 \mathrm{mg} / \mathrm{dl})$.

Increment of total bilirubin and direct bilirubine levels in rats treated with MHFD (hyperlipidemia) comparing with control may be due to liver cell damage or metabolic disturbance in liver involving defective conjugation and or extraction of bilirubin. Results show that administration of annona muricata at dose $200 \mathrm{mg} / \mathrm{kg}$ is better than dose $300 \mathrm{mg} / \mathrm{kg}$.

\subsubsection{Effect of ethanolic extract of Annona on protein fraction (total protein ,albumin and globulin)of hyperlipidemia rats after 8 weeks \\ The mean values of serum total protein, albumin and globulin of hyperlipidemic rats are presented in table (8).}

Table 8. Effect of ethanolic extract of Annona on protein fraction of hyperlipidemia rats after 8 weeks:

\begin{tabular}{lcccc}
\hline \multicolumn{1}{c}{ Treatments } & $\begin{array}{c}\text { Total protein } \\
(\mathbf{g} / \mathbf{d l})\end{array}$ & Albumin $(\mathbf{g} / \mathbf{d l})$ & Globulin $(\mathbf{g} / \mathbf{d l})$ & A/G Ratio \\
\hline Control negative & $7.15 \pm 0.21^{\mathrm{ab}}$ & $3.49 \pm 0.13 \mathrm{abc}$ & $3.66 \pm 0.28^{\mathrm{b}}$ & $0.97 \pm 0.10^{\mathrm{ab}}$ \\
Control positive & $6.46 \pm 0.17_{\mathrm{b}}$ & $3.10 \pm 0.04 \mathrm{bcd}$ & $3.36 \pm 0.14^{\mathrm{b}}$ & $0.93 \pm 0.03^{\mathrm{ab}}$ \\
HFD + Atrovastitine drug & $7.45 \pm 0.09^{\mathrm{ab}}$ & $3.68 \pm 0.26 \mathrm{ab}$ & $3.77 \pm 0.18^{\mathrm{ab}}$ & $0.98 \pm 0.12^{\mathrm{ab}}$ \\
$\mathbf{1 0 0 m g / k g}$ & $7.51 \pm 0.65^{\mathrm{ab}}$ & $3.17 \pm 0.56^{\mathrm{bcd}}$ & $4.34 \pm 0.36^{\mathrm{ab}}$ & $0.75 \pm 0.15^{\mathrm{bc}}$ \\
HFD+Annona 200mg/kg & $8.08 \pm 0.46^{\mathrm{a}}$ & $4.21 \pm 0.18^{\mathrm{a}}$ & $3.86 \pm 0.62^{\mathrm{ab}}$ & $1.15 \pm 0.20^{\mathrm{a}}$ \\
HFD+Annona 300mg/kg & &
\end{tabular}

$\mathrm{a}, \mathrm{b} \& \mathrm{c}$ :There is no significant difference $(\mathrm{P}>0.05)$ between any two means, within the same column have the same superscript letter.

Comparing of administration annona muricata extracts level (200 and 300mg/kg) with control rats group showed non-significant differences. The mean values were $(7.51 \pm 0.65,8.08 \pm 0.46 \mathrm{~g} / \mathrm{dl})$ for total protein, $(3.17 \pm 0.56$ and $4.21 \pm 0.18 \mathrm{~g} / \mathrm{dl})$ for albumin and $(4.34 \pm 0.36$ and $3.86 \pm 0.62 \mathrm{~g} / \mathrm{dl})$ for globulin at the two level of annona muricata extract respectively.

The obtained results referred that annona extracts improved the level of serum total protein, albumin and globulin. This improvement could be due to high polyphenolic content, antioxidant properties and its capacity to restore the functionality of the hepatic cell and reduce endoplasmic reticulum oxidation stress (Hashemi etal,2013) .

4.4. Effect of ethanolic extract of Annona on Kidney function of hyperlipidemia rats after 8 weeks

Results recorded in table (9) indicate that hyperlipidemic rats had the highest mean values of urea, uric acid and than that of control rats and atrovastitine drug .

Oral administrations of annona muricata at (200and $300 \mathrm{mg} / \mathrm{kg}$ ) showed that urea, uric acid and creatinine contents had significant decreased in values comparing with hyperlipidemic rats, parameters showed non-significant difference comparing with control negative rats.

Increment of kidney functions parameters levels in hyperlipidemic rats may be due to metabolic reflected in high active of xanthine oxidase,lipid peroxidation and increment of triglycerides and cholesterol (Anwar and Meki,2003). Moreover protein glycation in hyperlipidemic may be lead to muscle wasting and increase release of purine, the main source of uric acid as well as inactivity of xanthineoxidase (Eidi etal,2006). Oral administration $200 \mathrm{mg} / \mathrm{kg}$ annona muricata extract had significant lower values for urea , uric acid and creatinine comparing with hyperlipidemic rats group and non significant with control rats group. These results are in agreement with those reported by (Nwaneri, 2016).High quantity of flavonoids, tannins and other bioactive compounds in different fraction could be responsible for the protective effects the oxidative stress in 
kidney of rats (Vardaves etal, 2006 and Alpinar etal,2009).

Table 9. Effect of ethanolic extract of Annona on Kidney function of hyperlipidemia rats after 8 weeks

\begin{tabular}{lccc}
\hline Treatments & Urea $(\mathbf{m g} / \mathbf{d l})$ & Uric acid & Creatinin $(\mathbf{m g} / \mathbf{d l})$ \\
\hline Control negative & $45.30 \pm 1.42^{\mathrm{c}}$ & $3.40 \pm 0.05^{\mathrm{c}}$ & $1.29 \pm 0.06^{\mathrm{c}}$ \\
Control positive & $57.97 \pm 5.24^{\mathrm{ab}}$ & $4.60 \pm 0.15^{\mathrm{a}}$ & $6.20 \pm 0.23^{\mathrm{a}}$ \\
HFD + atorvastetein drug & $47.17 \pm 1.94^{\mathrm{c}}$ & $3.53 \pm 0.20^{\mathrm{c}}$ & $1.30 \pm 0.08^{\mathrm{c}}$ \\
$\mathbf{1 0} \mathbf{~ m g / k g}$ & $52.40 \pm 1.29^{\mathrm{bc}}$ & $3.69 \pm 0.08^{\mathrm{c}}$ & $1.49 \pm 0.04^{\mathrm{c}}$ \\
HFD+Annona 200 mg/kg & $61.13 \pm 0.72^{\mathrm{a}}$ & $4.37 \pm 0.09^{\mathrm{ab}}$ & $3.80 \pm 0.53^{\mathrm{b}}$ \\
\hline HFD+Annona 300 mg/kg &
\end{tabular}

$\mathrm{a}, \mathrm{b} \& \mathrm{c}$ : There is no significant difference $(\mathrm{P}>0.05)$ between any two means, within the same column have the same superscript letter.

4.4.5. Effect of Annona ethanolic extract on Lipid profile (total lipid, triglcerides, total cholesterol,HDL-cholesterol and LDL -

cholesterol) of hyperlipidemia rats after 8 weeks:

Table 10. Effect of ethanolic extract of Annona on Lipid profile of hyperlipidemia rats after 8 weeks:

\begin{tabular}{lcccccc}
\multicolumn{1}{c}{ Treatments } & $\begin{array}{c}\text { Total lipids } \\
(\mathbf{m g} / \mathbf{d l})\end{array}$ & $\begin{array}{c}\text { Triglycerides } \\
(\mathbf{m g} / \mathbf{d l})\end{array}$ & $\begin{array}{c}\text { Total } \\
\text { cholesterol } \\
(\mathbf{m g} / \mathbf{d l})\end{array}$ & $\begin{array}{c}\text { HDL } \\
(\mathbf{m g} / \mathbf{d l})\end{array}$ & LDL (mg/dl) & $\begin{array}{c}\text { vLDL } \\
(\mathbf{m g} / \mathbf{d l})\end{array}$ \\
\hline $\begin{array}{l}\text { Control negative } \\
\text { Control positive }\end{array}$ & $462.00 \pm 7.00^{\mathrm{c}}$ & $36.40 \pm 0.86^{\mathrm{de}}$ & $152.33 \pm 2.74^{\mathrm{f}}$ & $54.66 \pm 1.17^{\mathrm{a}}$ & $90.40 \pm 3.44^{\mathrm{e}}$ & 7.28 \\
$\begin{array}{l}\text { HFD } \\
\begin{array}{l}\text { Atorvastetein drug } \\
\mathbf{1 0 m g / k g}\end{array}\end{array}$ & $318.33 \pm 11.46^{\mathrm{a}}$ & $173.09 \pm 1.76^{\mathrm{a}}$ & $233.67 \pm 3.04^{\mathrm{a}}$ & $32.17 \pm 1.13^{\mathrm{f}}$ & $166.57 \pm 4.59^{\mathrm{a}}$ & 27.41 \\
$\begin{array}{l}\text { HFD+Annona } \\
\mathbf{2 0 0 m g / k g}\end{array}$ & $444.00 \pm 21.66^{\mathrm{c}}$ & $33.53 \pm 0.75^{\mathrm{e}}$ & $184.97 \pm 3.15^{\mathrm{c}}$ & $48.74 \pm 0.79^{\mathrm{b}}$ & $129.51 \pm 2.61^{\mathrm{bc}}$ & 6.70 \\
$\begin{array}{l}\text { HFD+Annona } \\
\mathbf{3 0 0 m g / k g}\end{array}$ & $530.33 \pm 6.64^{\mathrm{b}}$ & $47.00 \pm 1.02^{\mathrm{b}}$ & $206.07 \pm 2.80^{\mathrm{b}}$ & $38.40 \pm 1.14^{\mathrm{e}}$ & $158.26 \pm 2.07^{\mathrm{a}}$ & 9.40 \\
\hline
\end{tabular}

$\mathrm{a}, \mathrm{b} \& \mathrm{c}$ : There is no significant difference $(\mathrm{P}>0.05)$ between any two means, within the same column have the same superscript letter.

From the above mentioned results it could be observed that the oral ethanolic extracts of Annona at $(200$ and $300 \mathrm{mg} / \mathrm{kg}$ ) showed significant decrease in the levels of total lipids, triglycerids, total cholesterol and LDL-cholesterol while, HDL-cholesterol showed increment in its values comparing with positive control.The decrements of value may be due to the ethanolic extract containg of phenol and flavonoides which reduce lipid production in liver and liver peroxidation (Borradile etal 2003). The obtained results indicated that the best dose of ethanolic extract of Annona was $(200 \mathrm{mg} / \mathrm{kg})$. Those results are in agreement with these reported by Adeyemi et al (2008).

\section{Reference}

A.O.A.C. 2005. Method of analysis associtation of official Agriculture Chemists. Washington D.C.USA, $17^{\text {th }} \mathrm{ed}$.

Adaramoye, O.A.; , Olajumoke, A.; Jonah, A., and Michael, A F.2008. Lipid-lowering effects of methanolic extract of Vernonia amygdalina leaves in rats fed on high cholesterol diet. Vasc Health Risk Manag. 2008 Feb; 4(1): 235-241.

Adeyemi, D.O.; Komolafe, O.A.; Adewole, O.S.; Obuotor, E.M.; Abiodun, A.A., and Adenowo
,T.K. 2010. .Histomorphological and morphometric studies of the pancreatic islet cells of diabetic rats treated with extracts of Annona muricata. Folia Morphol (Warsz). May;69(2):92100.

Adeyemi, D.O.; Komolafe, O.A.; Adewole, S.O.; and Obuotor, E.M. 2008. Anti hyperlipidemic activities of Annona muricata (Linn). Internet $J$. Altern. Med., 7, 1.

Alpinar, K.;Ozyurek,M.; Kolak,U.; Guclu,K. and Apok,R. 2009. Antioxidant capacities of some food plants widely grown in Turkey.J.Food.Sci and Tec.Research,(15):59-64.

Anwar,M.M. and Meki,A.M. 2003.Oxidative stress in streptozotocin inducef diabetic rats :effect of garlic oil and melatonin.Comp.Biochem.Physiol.,135:539-547.

AOAS 1990. In official methods and recommended practices of the American Oil Chemists Society (4th ed). Champaign: American Oil Chemists Society.

Ahalya, B.; Shankar, K.R. and Kiranmayi, G. 2014. Exploration of anti-hyperglycemic and hypolipidemic activities of ethanolic extract of Annona muricata bark in alloxan induced diabetic rats. Int. J. Pharm. Sci. Rev. Res., 25, 21-27. 
Barakat, L.A.A. and Mahmoud R.H., 2011. The antiatherogenic, renal protective and immunomodulatory effects of purslane, pumpkin and flax seeds on hypercholesterolemic rats. North American Journal of Medical Sciences, 3(9): 351-357.

Baskar, R.; Rajeswari, V. and Kumar, T.S. 2007.In vitro antioxidant studies in leaves of Annona species. Indian J. Exp. Biol. 2007, 45, 480-485.

Borradaile ,N.M. ; Dreu,L.E and Huff,M.W.2003. inhibition of net hep G2 cell apolipoprotion B secretion by citrus flavonoid involves activation of phosphatidylinositol 3-kinase independent of insulin receptor substrate phosphorylation diabetic. 52(10):2554-2561.

Carle, P.; Lillian, B.; Ana Maria, C. and Isabel, C.F.R.F. 2010. Nutritional composition and bioactive properties of commonly consumed wild greens: potential sources for new trends in modern diets .iferreira@ipb.pt.

Chunhua, Y.; Sushma, R.G.; Rao, M.; Subrahmanyam, V.; Michelle, D.Re. and Ritu, A. 2015.Synergistic interactions among flavonoids and acetogenins in Graviola (Annona muricata) leaves confer protection against prostate cancer. Carcinogenesis, Vol. 36, No. 6, 656-665.

De Sousa, O.V.; Vieira, G.D.; De Jesus, R. G.; De Pinho, J.; Yamamoto, C.H., and Alves, M.S. 2010. Antinociceptive and antiinflammatoryactivities of the ethanol extract of Annona muricata L. leavesin animal models. Int. J. Mol. Sci., 11: 2067-2078.

Di Stasi ,L.C. and Hiruma-Lima, C.A. .2002. Plantas Medicinais na Amazônia e na Mata Atlântica, 2nd Ed. Editora UNESP, SãoPaulo, Brazil, 87-112. doi:10.3390/ijms 19061791. www.mdpi.com/journal/ijms

Eidi, A.; Eidi, M. and Esamae,E. 2006 Antidiobetic effect of allium-sativum in normal and streptozotcin-induced diabetic rats. Phytomedicine 13(10):624-629.

Fukushima, M. ;Takayama, Y.; Habaguchi, T. and Nkano, M. 1997.comparative hypocholesterolemic effects of capybara Hydrochoerus hydrochacaeris dannenei oil, horse oil and sardine oil in cholesterolfed rats. Lipid ,32(4):391-395.

George, V.C.; Kumar, D.R.N.; Rajkumar, V. ;Suresh, P.K., and Ashok, K.R. 2012. Quantitative Assessment of the Relative Antineoplastic Potential of the n-butanolic Leaf Extract of Annona Muricata Linn. in Normal and Immortalized Human Cell Lines. Asian Pacific Journal of Cancer Prevention, Vol 13, 699-704.

Gulcin,I.;Gungor, I.; Beydemir,S.S.; Elmasta,M. and Kuferevioglu,I. 2004.Comparison of antioxidant activity of clove (Eugenia caryophylata Thunb) buds and lavender
(Lavandula stoechas L.) Food Chem., 87:393400.

Hanato,T.; Kagawa,H.; Yasuhara,T. and Okuda,T. 1988.two new flavonoids and other constituents in licorice root: Their relative astringency and radical scavenging effects. hemical \& pharmaceutical bulletin 36(6):2090-7.

Hashemi,K.;Parivas,K.;Azghadi,N. and Goli,A. 2013.Pomegranate reduces endoplasmic reticulum stress induced by renal ischemia reperfusion injury in rats.Turkish Journal of Biology,37(4):464-471.

Jayasooriya, A., N. ;Sakono, C. ;Yukizaki, M. ;Kawano, K. ;Yamamoto, N. and Fukerda,N. 2000. Effect of Momordica charantia powder on serum glucose levels and various lipid parameters in rats fed with cholesterol enriched rats. J Ethnoparmacol., 72: 331-336.

Kimbonguil, A.A. ;Nzikou, J.M. and Matos, L. 2010. Proximate composition and physicochemical properties of the seed and oil of annona muricata grown in congo Brazzaville. Research J. of Environmental and Earthsciences ,2:13-18.

Laster,J.N and Birkeh,J.W. 1999. Microbiology and chemistry for Environmental scientists and Engineers. $2^{\text {nd }}$ ED.New fetter lane,London,p.386.

Liaw, C. C.; Chang, F.R.; Lin, C.Y.; Chou, C.J.; Chiu, H.-F.; Wu, M.-J.and Wu, Y.-C. 2002. New cytotoxic monotetrahydrofuran annonaceous acetogenins from Annona muricata. J. Nat. Prod., $65,470-475$.

Loliger,J. 1991. the use of antioxidant in foods.In free radicals and food additives.London:Tayler and Francis.

Nwaneri, C.V. 2016.Sub-Acute Tocixicty Studies Of ethanoland n-hexane crude extracts of Annona muricata in albino rats. futa journal of research in sciences 11(2): 281-291.

Oberlies, N.H.; Chang, C.J., and McLaughlin,J.L. 1997. Structure-activity relationships of diverse Annonaceous acetogenins against multidrug resistant human mammary adenocarcinoma (MCF - 7/Adr) cells. J Med Chem. 1997;40(13):2102-2106.

Ordon,J.D.; Gomez,M.A.;and Vattuone,M.I.2006. Antioxidant activities of Sechium edule (Jacp) . Swarez extracts. Food Chem 97:452-458.

Padma, P. 1997. Phytochemical studies and Evaluation ofBiological activity of some Medicinal Plants, PhD Thesis, Department of Pharmaceutics, Banaras Hindu University, Varanasi, 141-195.

Padma, P.; Khosa, R.L., and Sahai, M. 1996. Acetogenin fromGenus Annona - A Review, Indian Journal of NaturalProducts, 12(3): 3-21.

Prakash, A. 2007. Assessing bias in experiment design for large scale mass spectrometry-based quantitative proteomics. Mol Cell Proteomics 6(10):1741-8 
Re,R.; Pellegrini,N.; Proteggenete,A.;Pannala,A.; Yang,M. and Rice-E.C.1999. antioxidant activity applying an improved ABTS radical cation decolorization assay . Free Radic.Biol.Med.,26:1231-1237.

Sakr, C.J; Symons, J.M. ; Kreckmann, K.H. and Leonard, R.C.2009. Ischaemic heart disease mortality study among workers with occupational exposure to ammonium perfluorooctanoate. Occupational and environmental medicine 66(10):699-703.DOI:

10.1136/ oem.2008.041582.

Skerget M.; Kotnik, P.; Hadolin, M.; Rizner Hras, A.; Simonic,M.and Kenze,Z. 2005.Phenols, proanthocyanidins, flavones and flavonols in some plant materials and their antioxidant activities . Food Chem.,89:191-198.

Steel, R.; Torrie, J. and Dickey, D. 1997. Principles and Procedures of statistics: A Biometrical, 3rd ed, McGraw-Hill, New York, NY.

Sousa, M.P.;Matos, M.E.O.;Matos, F.J.A.; Machados, M.I.L., and Craveiro, A.A. 2004. Constituintes Químicos Ativos e Propriedades Biológicas de Plantas Medicinais Brasileiras, 2nd Ed. Editora UFC, Fortaleza, Brazil, 281-283.
Sulaiman, H.; Roslida, A.H.; Fezah, O.; Tan, K.L.; Tor, Y.S., and Tan, C.I. 2012. Chemopreventive Potential of Annona muricata L Leaves on Chemically Induced Skin Papillomagenesis in Mice. Asian Pac J Cancer Prev.; 13: 2533-9.

Vardaves , C.I.; Majchrzah,D.; Wagnez,K. and Kafatos, A.2006. The antioxidant and phylloquinone contant of widely grown greens in crete. J.Food chemistry.(99):813-821.

Vijayameena, C.; Subhashini, G.; Loganayagi, M.; Ramesh, B.2013. Phytochemical screening and assessment of antibacterial activity for the bioactive compounds in Annona muricata. Int. J. Curr. Microbiol. Appl. Sci 2013, 2, 1-8.

Weber, D.K.; Danielson, K.; Wright,S. and Foley, J.E. 2002. Hematology and serum biochemistry values of dusky footed wood rat. J.Wild Life Diseases,38(3):576-582.

Yahaya, G.;Faten, A.E.; Fred, W. and Hany, A. E.S.2014.GC-MS Analysis of Bioactive Phytochemicals Present in Ethanolic Extracts of Leaves of Annona muricata: A Further Evidence for Its Medicinal Diversity. Pharmacognosy Journal, Vol 7, Issue 5,300-304 